\author{
Carme Rissech, ${ }^{1}$ Ph.D.; Nicholas Márquez-Grant, ${ }^{2,3}$ Ph.D.; and Daniel Turbón, ${ }^{1}$ Ph.D.
}

\title{
A Collation of Recently Published Western European Formulae for Age Estimation of Subadult Skeletal Remains: Recommendations for Forensic Anthropology and Osteoarchaeology*
}

\begin{abstract}
The aim of this study is to provide an effective and quick reference guide based on the most useful European formulae recently published for subadult age estimation. All of these formulae derive from studies on postnatal growth of the scapula, innominate, femur, and tibia, based on modern skeletal data (173 $\hat{\gamma}, 173$ + $)$ from five documented collections from Spain, Portugal and Britain. The formulae were calculated from Inverse Regression. For this reason, these formulae are especially useful for modern samples from Western Europe and in particular on 20 th century human remains from the Iberian Peninsula. Eleven formulae were selected as the most useful because they can be applied to individuals from within a wide age range and in individuals of unknown sex. Due to their high reliability and because they derive from documented European skeletal samples, we recommend these formulae be used on individuals of Caucasoid ancestry from Western Europe.
\end{abstract}

KEYWORDS: forensic science, forensic anthropology, subadult age-at-death estimation, postnatal growth, maturation, formulae

Methods of age-at-death estimation in infant and juvenile remains rely on the degree of skeletal and dental development. Based on the biological (skeletal) age of the individual at the time of death, these methods provide a specific age range derived from the degree of skeletal maturation and growth.

To obtain an age at death, it is essential to understand the normal pattern of growth and maturation of every skeletal element and to develop their respective growth models. These growth models must be devised from studies on documented skeletal collections where there is information on age, sex, ancestry, cause of death, and any pathological condition during life (1). Even better if the demographic, socio-economic, and temporal context in which the individuals lived is also known (2).

However, despite the importance of these types of studies, there is still a gap in the number of studies on growth and development based on measurements directly taken on human skeletal remains. Some of the available standards today comprise studies

\footnotetext{
1Unidad de Antropelogía Física, Department of Biolegía Animal, Facultad de Biología, Universidad de Barcelona, Barcelona, Spain.

${ }^{2}$ Institute of Human Sciences, School of Anthropology and Museum Eth$\equiv$ phy, University of Oxford, Oxford, U.K.

$1 \equiv$ llmark Forensic Services, Abingdon, U.K.

*Presented in part at the 11th Annual Conference of the British Association for Biological Anthropology and Osteoarchaeology (BABAO), September 18-20, 2009, in Bradford, U.K.; and at the 17th Congress of the European Anthropological Association (EAA), August 30-September 2, 2010, in Poznan, Poland.
}

Received 10 June 2011; and in revised form 27 Dec. 2011; accepted 30 Dec. 2011. on radiological data from White Americans (3-9) or studies based on archaeological material (10-13). The absence of standards directly derived from skeletal remains mainly lies in the lack of subadult skeletal material with known biological profile such as age at death (14). Thus, in recent years, and to solve this problem, some authors (15-24) after a number of analyses have considered as a homogeneous group the few osteological collections, which exist in Western Europe with the objective of developing growth models to provide more population-specific age and sex estimation methods. Many of these studies have been carried out on the sacrum (25), femur (20,23), tibia (24), scapula $(26,27)$, and innominate (16-19,21,22,28). These studies are important for a number of reasons. First, they are the first studies on postnatal growth (from birth to adult age) based on documented and contextualised modern skeletal remains (samples from the late 19th century to the end of 20th century) from Western Europe (U.K., Spain and Portugal); and second, they are appropriate and reliable when analyzing modern European Caucasoid skeletal remains from this geographical area. In addition, these formulae can be applied to skeletal material of unknown sex, providing a low degree of error (see Fig. 1).

These studies, however, are not well known. This may be partly due to their separate publication in different journals; and partly due to the fact that many of these publications do not provide comprehensible information for the field or laboratory anthropologist who needs a quick reference guide with the formulae. Many of these published works provide invaluable information on the growth of each skeletal element, its mathematical expression and formulae for subadult age estimation, but 
Collections

\begin{tabular}{|c|c|c|c|c|c|}
\hline Rissech, et al. (20) & $\mathrm{Sch}, \mathrm{SBr}, \mathrm{Co}, \mathrm{Lis}, \mathrm{U}$ & Age $=0.560 \times$ Vertical diameter of the femoral head -7.890 & 0.890 & 1.03 & Up to $15 \mathrm{y}$. \\
\hline Rissech, et al. (20) & $\mathrm{Sch}, \mathrm{SBr}, \mathrm{Co}, \mathrm{Lis}, \mathrm{U}$ & Age $=0.05583 \times$ Diaphyseal length of the femur -6.37286 & 0.890 & 0.73 & Up to $16 \mathrm{y}$. \\
\hline Rissech and Black (26) & Sch & Age $=0.140472 \times$ Scapular length -5.059151 & 0.890 & 1.72 & Up to $16 \mathrm{y}$. \\
\hline Rissech and Black (26) & Sch & Age $=0.186 \times$ Sca pular spine length -6.1000 & 0.970 & 1.32 & Up to $19 \mathrm{y}$. \\
\hline Rissech and Black (26) & Sch & Age $=0.262093 \times$ Scapular width -7.489091 & 0910 & 1.38 & Up to $19 \mathrm{y}$. \\
\hline Rissech and Black (26) & Sch & Age $=0.528610 \times$ Supra-scapular height -6811764 & 0.840 & 2.09 & Up to $19 \mathrm{y}$. \\
\hline Rissech and Black (26) & Sch & Age $=-0.012320 \times(\text { Acromial width })^{2}+1.068638 \times$ Acromial width -5.069435 & 0920 & 129 & Up to $16 \mathrm{y}$. \\
\hline Rissech et al. (18) & $\mathrm{SBr}, \mathrm{Co}$, Lis $\mathrm{UAB}$ & Age $=0310129 x$ Ischium length -8.788776 & 0.900 & 1.51 & Up to $20 \mathrm{y}$. \\
\hline Rissech and Malgosa (21) & $\mathrm{SBr}, \mathrm{Co}$, Lis, UAB & Age $=-2.820471 .10^{5} \times(\text { llium width })^{3}+0.008672 x$ (llium width $)^{2}-0.639609 x$ Ilium width +14.586156 & 0.929 & 1.15 & Up to $20 \mathrm{y}$. \\
\hline Rissech and Malgosa (21) & $\mathrm{SBr}, \mathrm{Co}$, Lis, UAB & Age $=-4.16322 .10^{-5} x$ (llium length $)^{3}+0.010835 x$ (llium length $)^{2}-0.678840 x$ Ilium length +12.783241 & 0.920 & 1.27 & Up to $16 \mathrm{y}$. \\
\hline López-Costas et al. (24) & $\mathrm{SBr}, \mathrm{C}_{0}, \mathrm{Lis} \mathrm{UAB}$ & Age $=0.066 \times$ Diaphyseal length of the tibia -5.656 & 0.871 & 1.18 & Up to $17 \mathrm{y}$. \\
\hline
\end{tabular}
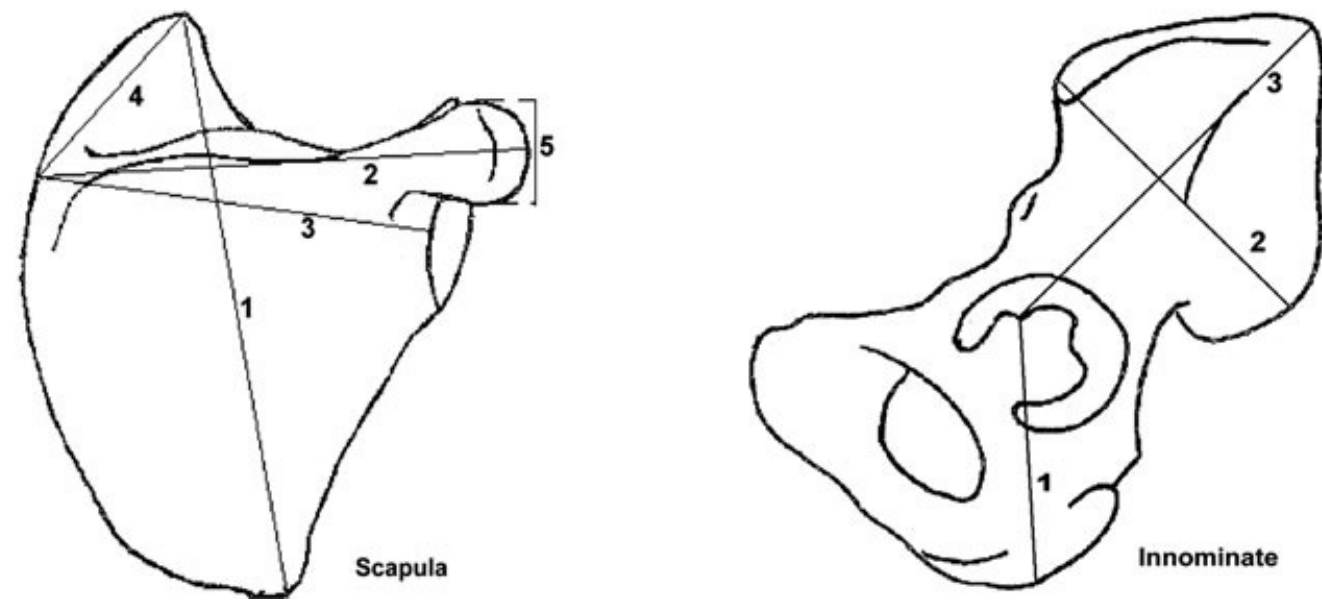

FIG. 1-Unisex functions for the estimation of age-at-death in sub-adult skeletons. The age limit for its application ranges from 1 year old to the age 4 indicated in the figure. Codes: Scapula: 1- scapular length, 2- scapular spine length, 3- scapular width, 4- supra-scapular height, 5- acromial width. Innominate: 1- ischium length, 2- ilium width, 3-ilium length. Sch, Scheuer collection; SBr, St Bride collection; Co, Coimbra collection; Lis, Lisboa collection. Average error means the average absolute error (|estimated age-chronological age| $/ n$ ) found when the formula is applied in the analysed skeletal collections. $R_{\perp}$ mean correlation coefficient.

do not focus on making it particularly applicable ("user friendly") to field anthropologists. Therefore, the main objective of this study is to collate the models primarily based on the work of the first author (CR) and colleagues and to provide in a clear manner the formulae that are most useful for age at death and clear instructions on how to use these. It is hoped that this will result in providing a quick reference guide for application in the field and in the laboratory.

\section{Models and Bibliographical Review}

A number of models have been selected that are based on European populations (Portugal, Spain and Britain) and provide accurate results from a number of skeletal elements. These models used a sample constituted by five skeletal collections of documented biological identity:

- Esqueletos Identificados curated at the Museu Antropologico at Coimbra University in Coimbra (Portugal). This collection consists of 505 adult and subadult individuals from the local cemetery of Conchada. All the individuals were born between the late 19th and late 20th centuries (29).

- Lisbon collection curated at the Museu Bocage in Lisbon (Portugal). This collection comprises adults and subadults skeletons from three local cemeteries of Alto de S. Joaõ, Prazeres, and Benfica. It consists of 1400 individuals, who were born between the late 19th and late 20th centuries (30).

- Universitat Autònoma de Barcelona (UAB) collection, housed at the Unit of Biological Anthropology of the UAB (Spain). This series arose from the accumulation of 36 adult individuals from the cemetery of Granollers (Spain) who were born in the 20th century (2).

- St. Bride's collection held at the crypt of St Bride's church in London (U.K.). This collection consists of 227 adults and sub-adults born between the late 18th and late 19th centuries, originating from the church cemetery (31).

- Scheuer collection, housed at the Centre of Anatomy and Forensic Anthropology of the University of Dundee (Scotland). There are over 100 subadult individuals whom derive from archaeological, forensic, and anatomical collections, many of which are documented $(15,32)$.

All the individuals analyzed for the publications from which the formulae derive have documented biological identity, and records of birth and death are available. They were born mainly in the 20th century, although there are a small number of skeletons which date to the late 19th century. Details regarding age and sex are provided in Table 1. 
TABLE 1-Distribution of specimens by sex, age and population.

\begin{tabular}{|c|c|c|c|c|c|c|c|c|c|c|c|c|}
\hline \multirow[b]{2}{*}{ Age } & \multicolumn{2}{|c|}{$\mathrm{Sb}$} & \multicolumn{2}{|c|}{ Co } & \multicolumn{2}{|c|}{$\mathrm{Lb}$} & \multicolumn{2}{|c|}{ UAB } & \multicolumn{2}{|c|}{ Sch } & \multicolumn{2}{|c|}{ Total } \\
\hline & $\mathrm{m}$ & $\mathrm{f}$ & $\mathrm{m}$ & $\mathrm{f}$ & $\mathrm{m}$ & f & $\mathrm{m}$ & $\mathrm{f}$ & $\mathrm{m}$ & $\mathrm{f}$ & $\mathrm{m}$ & f \\
\hline $0-4$ & 3 & 1 & & & 11 & 5 & & & 4 & 3 & 18 & 9 \\
\hline $5-9$ & 5 & & 2 & 4 & 4 & 4 & & & 1 & 2 & 12 & 10 \\
\hline $10-14$ & 1 & 1 & 2 & 11 & 2 & 4 & & & & 4 & 5 & 20 \\
\hline $15-19$ & 1 & 2 & 11 & 13 & 6 & 6 & & & 2 & 3 & 20 & 24 \\
\hline $20-25$ & 5 & 4 & 11 & 8 & 5 & 12 & & & & & 21 & 24 \\
\hline $26-30$ & 2 & 3 & 6 & 4 & 5 & 56 & & & & & 13 & 13 \\
\hline $31-35$ & 2 & 3 & 3 & 1 & 5 & 6 & 2 & & & & 12 & 10 \\
\hline $36-45$ & 5 & 7 & 9 & 6 & 9 & 6 & 1 & & & & 24 & 19 \\
\hline $46-55$ & 3 & 5 & 5 & 5 & 9 & 7 & 3 & & & & 20 & 17 \\
\hline 56-65 & 11 & 4 & & & & & 5 & 1 & & & 16 & 5 \\
\hline $66-75$ & 3 & 5 & & & & & 3 & 4 & & & 6 & 9 \\
\hline \multirow[t]{2}{*}{ 76-97 } & 1 & 3 & & & & & 5 & 10 & & & 6 & 13 \\
\hline & 42 & 38 & 49 & 52 & 56 & 56 & 19 & 15 & 7 & 12 & 173 & 173 \\
\hline
\end{tabular}

Males are indicated by " $m$ " and females are indicated by "f".

$\mathrm{Sb}$, St. Bride's collection, London; Co, collection of Esqueletos Identificados of Coimbra; Lb, Lisbon collection; UAB, collection of the Universitat Autònoma de Barcelona; Sch, collection of Scheuer of the University of Dundee.

Due to the chronology of these individuals, their provenance in Western Europe, their Caucasoid ancestry, the similarity in their pattern of growth (young individuals), and the absence of any significant differences between the series in adult individuals according each sex and metrical variable, these collections were considered as a single series. As stated earlier, the growth models created from these collections are primarily the work of the first author (CR) and colleagues on metric analysis of the tibia, femur, scapula, ilium, ischium and pubis (16-18,20-24,26-28) from individuals aged between 0 and 20 years. Eleven functions for subadult age estimation derived from these cited works have been selected based on their ease of application, the reliability of the results, as well as their use in most of the subadult cases where sex is unknown. Therefore, the variables that we consider of most use are those expressed by simple equations that can be applied to individuals of unknown sex and from a wide subadult age range.

\section{Recommended Formulae for Sub-adult Age Estimation}

In Fig. 1 are included the 11 formulae for subadult age estimation selected from these studies by considering an application for an individual of unknown sex. We omit the functions that need to be applied to sexes separately because the aim of this study is to provide the scientist with the most useful, and at the time most reliable, formulae for subadult age-at-death estimation.

We strongly recommend these formulae in particular when analyzing human remains from forensic cases in Western Europe, and especially those from the Iberian Peninsula and dating to the 20th century. They are especially useful when the skeleton is incomplete, and after the age of 12 years of age when dentition is less reliable. However, it is important to have the maximum biological information about the individual in question, for this reason, it is essential to ensure the use of as many indicators of age as possible. The measurements represented in Fig. 1 and described below can then be applied to the formulae in Fig. 1.

\section{Measurements}

\section{Measurements of the femur (20)}

- Diaphyseal length: maximum distance between the distal and proximal ends (metaphyseal) of the femoral shaft, excluding any epiphyses (33). If either the distal or proximal epiphyses have fused, the measurement is not valid.

- Vertical head diameter: measurement of the periphery of the articular surface of the femoral head, perpendicular to the antero-posterior diameter $(34,35)$.

\section{Measurements of the scapula (26)}

- Scapular length: maximum distance between the superior and inferior angles of the scapula $(33,36)$.

- Scapular width: distance between the posterior border of the glenoid rim and the medial end of the scapular spine $(33,36)$.

- Suprascapular height: distance between the point at which the axis of the scapular spine intersects the medial border of the scapula to the superior angle $(36,37)$.

- Acromial breadth: maximum width between the anterior and posterior borders of the acromion process, perpendicular to the axis of the scapular spine (26)

- Length of the scapular spine: maximum distance between the medial end of the spine and the tip of the acromion process $(33,38)$.

\section{Measurements of the innominate $(17,18,20-22)$}

- Ischium length: maximum distance from the anatomical acetabular point to the ischiatic tuberosity (39). The anatomical acetabular point (17) corresponds to the anatomical point at which the three elements of the innominate (ilium, ischium, pubis) unite. In fused acetabula, the acetabular fossa has an irregular clover-leaf shape, and the anatomical acetabular point corresponds always to the indentation between the superior and the anterior lobes of the acetabular fossa (17).

- Ilium length: maximum distance between the anatomical acetabular point (17) and the most distant point of the iliac crest (crestal point). It is the maximum chord length (40). In unfused or immature innominates, the crestal point corresponds to the highest point of the iliac crest (Fazekas and Kósa's (33) ilium breadth); and in individuals with adult morphology, the point is located according to the method proposed by Genovés (39).

- Ilium width: distance between the antero-superior and postero-superior iliac spine (40). To locate these, the method to be employed in unfused or immature innominates is that by Fazekas and Kosa's (33) ilium length. In individuals with an adult morphology, the method to follow is that proposed by Genovés (39).

\section{Measurements of the tibia (24)}

- Diaphyseal length of the tibia: Maximum distance between the proximal and distal ends (metaphyses) of the tibia shaft, excluding any epiphysis. This measurement is of no value if the distal epiphysis has begun to unite (33).

\section{Applying the Formulae}

The growth behavior of biological variables can be described by an incremental continuous function. In general terms, growth may be described as a low order polynomial $(41,42)$. For this reason, and as one of the first steps in these published studies, the growth of the variables was analyzed using polynomial regression up to the fifth degree, treating age as continuous. Only individuals still growing were used. Following that, and to 
enable predictions of age at death, Inverse Regression analysis for age and each metrical variable of the bone was calculated using age as dependent variable. That is to say, each metrical variable of the bone (x) was regressed on age (y). Inverse Regression was selected because it is the method of choice when there is some a priori reason for presuming that the case in question comes from the same distribution as represented within the reference sample (43), and this presumption is generally warranted in forensic settings (43) and in some paleoanthropological cases when there is some theoretical reason for a strong prior (43). There is, of course, some biological differentiation among Western European populations. However, this differentiation does not seem to greatly affect the variability observed during the growth of the skeletal elements that have been analyzed and are considered here. Their biological proximity is indicated by the similarity in their pattern of growth (24), and the low standard deviations (24) observed in the variables of these published studies. French and Portuguese populations are biologically similar to the Spanish, because of their shared biological population history and geographical proximity $(2,44)$. Furthermore, Rissech (16), in her study based on several documented skeletal collections from various Western European countries (Spain, Portugal and Britain), found that they could be considered as a single series due to the observed homogeneity. The algebraic simplicity of the functions obtained makes the application of the formulae for age estimation easy. However, as we stated earlier, their use is not risk-free since the accuracy of an estimated age is affected by the biological distance between the reference sample and the test sample. For this reason, the formulae proposed in these studies are, mainly, useful for modern Western European samples and particularly from the Iberian Peninsula.

\section{Applying the formulae to estimate age at death}

For the estimation of age at death, it is necessary to substitute the value or measurement in millimeters and apply it to the relevant calculation. The result is obtained in years (Fig. 2).

For example (Fig. 2), we obtain a diaphyseal length of the tibia of $203 \mathrm{~mm}$ in one individual. This measurement is applied to the formula for the diaphyseal length of the tibia (Age $=0.066 \times$ diaphyseal length of the tibia -5.656$)$, and the value of $203 \mathrm{~mm}$ is introduced (Age $=0.066 \times 203-5.656$ ) .

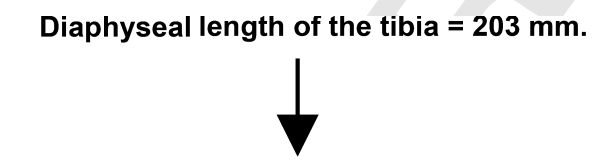

Age $=\mathbf{0 . 0 6 6} \times$ Diaphyseal length of the tibia $\mathbf{- 5 . 6 5 6}$

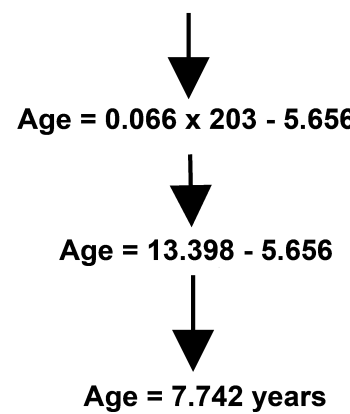

FIG. 2-Illustration with an example on how to apply the formulae on sub-adult skeletal remains in order to obtain an estimation of age-at-death.
The calculation produces an age in years (Age $=7.742$ years). If necessary, it is possible to add to this result the $95 \%$ confidence interval, which is given graphically or numerically by the studies in question. For example, in the study of the tibia, the confidence interval is given numerically (standard error), which is of 1.656 years in the case of the diaphyseal length. That means that the age confidence interval for the analyzed individual is $7.742 \pm 1.656$ years.

The chronological age of this tested individual is 7 years, and the error obtained during the estimation was an overestimation of 0,742 years $($ Error $=$ Estimated skeletal age - Chronological age $)$.

\section{Discussion and Conclusion}

This work has taken the growth models, which have derived from five Western European populations. The most useful functions have been selected and provided for the estimation of age at death in subadult individuals, followed by instructions on how to apply them. The aim of the work was to provide practitioners with a quick reference guide for its application in the field or laboratory.

As illustrated in Fig. 1, the formulae provided in this study have a low degree of error, and they are important for subadult age-at-death estimation both in archaeological and forensic contexts. Their importance is especially significant when it is taken into account that they are the only ones derived directly from documented subadult skeletal material from Western Europe, which are applicable to a wider rather than a narrower subadult age range without the need to know the sex of the individual.

These formulae are useful in subadult age estimation in forensic cases due to their representativeness of a modern population with regard to the growth parameters as the growth spurt, the timing of maturation and the cessation of growth of the variables of these published studies as is possible see in López-Costas et al. (24). These growth parameters indicate no delayed growth in the present series by comparing them to modern growth models. This conclusion is corroborated by the homogeneity observed in the maximum length of the adult femur (20) between these analyzed series, and the Spanish documented, and contextualised modern skeletal collection of the UAB. The UAB collection is made up exclusively of modern individuals from the industrial town of Granollers, which is an industrial, commercial, and trade city, situated $25 \mathrm{~km}$ northeast of Barcelona (2), and the femur is one of the bones that best correlates with stature (45), indicating the similarity in stature between the modern Spanish series and the series of these studies. In general, it can be said that the analyzed series do not show evidence of secular change, malnutrition, or delays in growth or osseous maturation and correspond to a modern Western European sample, specifically from the Iberian Peninsula.

The existence of formulae for individuals of specific regions is necessary and important. However, most of the current standards are based primarily from North American (U.S.A.) skeletal assemblages and the magnitude of the error in its application to European populations is unknown. For example, the method for calculating adult stature based on U.S.A. reference samples fails in the estimation of living height in Spain and Italy (45-47). For example, in Spain and Italy, the use of the formulae proposed by Pearson (48) at the end of 19th century, based on a French sample, performs better (45-47) than the Trotter and Gleser formulae for Whites, because of the intertwined biological population history of French, Spanish, and Italian populations (45-47), and because they are populations of medium stature $(45,46)$. In 
contrast, the equations of Trotter and Gleser for Whites systematically overestimate stature in both female and male skeletons of Spanish and Italian origin $(46,47)$. In subadults age estimation, for example, according to the data given by Gindhart (7) and Hoffman (8) studies based on a White American sample of North Western European descent, a tibial diaphyseal length of $203 \mathrm{~mm}$, as such of the present study, is situated in the lower limit of the expected normal variation range of growth (200$260 \mathrm{~mm}$ ) given by these authors for individuals of 7 years of age. For this reason, the estimated age (which is an average age of the normal range interval) for this individual is 4.5 years. To assume that all populations grow like those from the U.S.A. would not be exactly correct. It is known that the U.S.A. population is higher than most European populations (49-51), although it is also true that in recent years stature has increased in European due to improvements in living conditions, some differences still exist (52). In this way, the data presented in this study is very appropriate for Western European populations and especially for forensic cases from the Iberian Peninsula.

In fact, there is a need to abandon the notion of the "universality" of osteological methodology and rather, promote the standardisation of methods (53). Methodology should not be applied to skeletal material without regard for the secular and regional origin of the reference collection(s) used in the creation of the method. The formulae presented here based on data from a number of published studies is of great importance for physical anthropologists analyzing human remains from Western Europe, specifically from the Iberian Peninsula and the Western Mediterranean. We therefore strongly recommend their use in forensic cases and in some bioarchaeological cases when there was some reason for presuming a strong prior of similitude between the case and the sample in which the model was based.

\section{Acknowledgements}

C. Rissech would like to thank all the authors that have collaborated in previous studies. We are grateful to the Museum of London, University of Coimbra, Museu Bocage of Lisbon, the University of Dundee and the Universitat Autònoma de Barcelona, for providing access to their human skeletal collections. Study was Funded by the Ministerio de Ciencia e Innovación of Spain Research Project No. CGL2006-02170/BTE and the Generalitat de Catalunya Research Project 2009SGR884 GRQ-Grup d'Estudis d'Evolució d'Homínids i d'Altres Primats.

\section{References}

1. Humphrey LT. Growth patterns in the modern human skeleton. Am J Phys Anthropol 1998;105:57-72.

2. Rissech C, Steadman DW. The demographic, socio-economic and temporal contextualisation of the Universitat Autònoma de Barcelona collection of identified human skeletons (UAB Collection). Int J Osteoarch 2010;3:313-22.

3. Ghantus MK. Growth of the shaft of the human radius and ulna during the first two years of life. Am J Roentgenol 1951;65:784-6.

4. Reynolds EL. The bony pelvic girdle in early infancy. A roentgenometric study. Am J Phys Anthropol 1945;3:321-54.

5. Reynolds EL. The bony pelvis in prepuberal childhood. Am J Phys Anthropol 1947;5:165-200.

6. Maresh MM. Linear growth of the long bones of extremities from infancy through adolescence. Am J Dis Child 1955;89:725-42.

7. Gindhart PS. Growth standards for the tibia and radius in children aged one month through eighteen years. Am J Phys Anthropol 1973;39:41-8.

8. Hoffman JM. Age estimations from diaphyseal lengths: two months to twelve years. J Forensic Sci 1979;24:461-9.
9. Smith SL, Buschang PH. Longitudinal models of long bone growth during adolescence. Am J Phys Anthropol 2005;17:731-45.

10. Stloukal M, Hanáková H. Die Länge der längsknochen altslawischer belvökerungen, unter besonderer berücksichtigung von wachstumsfragen. Homo 1978;29:53-69.

11. Sundick RI. Human skeletal growth and age determination. Homo 1979;29:228-49.

12. Stewart TD. Identification by the skeletal structures. In: Camps FE, editor. Gradwohl's legal medicine. Bristol, U.K.: John Wright, 1976;123-54.

13. Boccone S, Micheletti-Cremasco M, Bortoluzzi S, Moggi-Cecchia J, Rabino-Massa E. Age estimation in subadult Egyptian remains. Homo 2010;61:337-58.

14. Rissech C. Estimación de la edad biológica de los restos subadultos. In: Gusi F, Muriel S, Olària C, editors. Nasciturus, infans, puerulus vobis mater terra: la muerte en la infancia. Castelló, Spain: Diputació de Castelló, Servei d'investigacions Arqueològiques i Prehistòriques, 2008;77-92.

15. Black S, Scheuer L. Age changes in the clavicle: from the early neonatal period to skeletal maturity. Int J Osteoarcheol 1996;6:425-34.

16. Rissech $\mathrm{C}$. Anàlisi del creixement del coxal a partir de material ossi i les seves aplicacions en la medicina forense i l'antropologia [Ph.D. dissertation]. Bellaterra, Barcelona, Spain: Universitat Autònoma de Barcelona, 2001.

17. Rissech C, Sañudo JR, Malgosa A. The acetabular point: a morphological and ontogenetic study. J Anatomy 2001;198:743-8.

18. Rissech C, García M, Malgosa A. Sex and age diagnosis by ischium morphometric analysis. Forensic Sci Int 2003;153:188-96.

19. Rissech C, Sañudo JR, Malgosa A. Punto acetabular anatómico: localización y aplicaciones Antropológicas y Forenses. In: Malgosa A, Nogués $\mathrm{R}$, Aluja P, editors. Antropología y biodiversidad. Barcelona, Spain: Ediciones Bellaterra, 2003;447-55.

20. Rissech C, Shaefer M, Malgosa A. Development of the femur-implications for age and sex determination. Forensic Sci Int 2008;180:1-9.

21. Rissech C, Malgosa A. Ilium growth study: applicability in sexual and age diagnostic. Forensic Sci Int 2005;147:165-74.

22. Rissech C, Malgosa A. Pubic growth study: applicability in sexual and age diagnostic. Forensic Sci Int 2007;173:137-45.

23. Rissech C, Malgosa A. El crecimiento del fémur en una muestra de Europa occidental documentada. In: Martínez-Almagro A, editor. Diversidad biológica y salud humana. Murcia, Spain: Fundación Universitaria San Antonio, 2007;451-7.

24. López-Costas O, Rissech C, Trancho G, Turbón D. Postnatal ontogénesis of the tibia. Implications for age and sex estimation. Forensic Sci Int 2012;3:207.e1-11.

25. Rios L, Weisensee K, Rissech C. Sacral fusión as and aid in age estimation. Forensic Sci Int 2008;180:111.e1-7.

26. Rissech C, Black S. Scapular development from neonatal period to skeletal maturity. A preliminary study. Int J Osteoarchaeol 2007;17:451-64.

27. Rissech C, Black S. El crecimiento de la escápula y su aplicación a la estimación de la edad de los individuos subadultos. In: Nieto Amada JL, Obón Nogués JA, Baena Pinilla S, editors. Genes, ambiente y enfermedades en poblaciones humanas. Zaragoza, Spain: Prensas Universitarias de Zaragoza, 2008;357-68.

28. Rissech C, Malgosa A. La longitud del isquion desde el nacimiento hasta la vejez: diagnóstico de edad y sexo. In: Varela $\mathrm{T}$, Bernis $\mathrm{C}$, editors. Investigaciones de biodiversidad humana. Santiago de Compostela, Spain: Universidad de Santiago de Compostela, 2000;350-7.

29. Rocha MA. Les collections ostéologiques humaines identifiées du Musseé Anthropologique de l'Université de Coimbra. Antropol Port 1995; 13:17-38.

30. Cardoso H. Brief communication: the collection of identified human skeletons housed at the Bocage Museum (National Museum of Natural History), Lisbon, Portugal. Am J Phys Anthropol 2006;129:173-6.

31. Black SM, Scheuer JL. A multidisciplinary approach to osteological research. J Paleopathol 1995;7:78.

32. Scheuer L, Black S. Developmental juvenile osteology. London, U.K.: Academic Press, 2000.

33. Fazekas GI, Kósa F. Forensic fetal osteology. Budapest, Hungary: Akadémiai Kiadó, 1978.

34. Pearson K. A study of long bones of English skeleton I: the femur. Londton, U.K.: University of London, University College, Department of Applied Statistics: Campus Research Memoirs, Biometric Series X, 1919; Chapters 1-4.

35. Olivier G. Pratique antropologique. Paris, France: Vigot Frères Éditeurs, 1960.

36. Broca P. Sur les indices de la largeur de l'omoplate chez l'home, les signes et dans la série des mammifères. Bull Mém Soc Anthropol París 1878;???:66-92. 
37. Vallois HV. L'omoplate humaine. Bull Mém Soc Anthropol París 1946;7:16-99.

38. Pospísil M. Manual de prácticas de antropología física. La Habana, Cuba: Editorial nacional de Cuba, Editora del consejo nacional de Universidades, 1965.

39. Genovés S. Diferencias sexuales en el hueso coxal. México City, Mexico: Universidad Nacional Autónoma de México, Publicaciones del Instituto de Historia, 1959.

40. Schultz AH. The skeleton of the trunk and limbs of higher primates. Hum Biol 1930;2:303-438.

41. Tanner JM. Growth at adolescence, 2nd rev. edn. Oxford, U.K.: Blackwell Scientific Publications, 1962.

42. Coleman WH. Sex differences in the growth of the human bony pelvis. Am J Phys Anthropol 1969;31:125-52.

43. Konigsberg LW, Hens SM, Jantz LM, Jungers WL. Stature estimation and calibration: Bayesian and maximum likelihood perspectives in physical anthropology. Yb Phys Anthropol 1998;41:65-92.

44. Márquez-Grant N, Rissech C, López-Costas O, Caro-Dobón L. Spain/ España. In: Márquez-Grant N, Fibiger L, editors. The Routledge handbook of archaeological human remains and legislation: an international guide to laws and practice in the excavation, study and treatment of archaeological human remains. London, U.K.: Routledge Editorial, 2011;423-38.

45. Formicola V, Franceschi M. Regression equations for estimating stature from long bones of early Holocene European samples. Am J Phys Anthropol 1996;100:83-8.

46. Formicola V. Stature reconstruction from long bones in ancient population samples: an approach to the problem of its reliability. Am J Physical Anthropol 1993;90:351-8.
47. Lalueza-Fox C. Stature and sexual dimorphism in ancient Iberian populations. Homo 1998;49:260-72.

48. Pearson K. Mathematical contributions to the theory of evolution. On the reconstruction of the stature of prehistoric races. Phil Trans R Soc Lond 1899;192:169-244.

49. Komlos J, Baur M. From the tallest to (one of) the fattest: the enigmatic fate of the size of the American population in the Twentieth Century. Econ Hum Biol 2004;2:57-74.

50. Komolos J. On the biological standard of living of eighteenth-century Americans: taller, richer, healthier. Res Econ Hist 2001;??2:223-48.

51. Smith SA, Norris BJ. Changes in the body size of U.K. and US children over the past three decades. Ergonomics 2004;47:1195-207.

52. Pebles L, Norris B. ADULTDATA: the handbook of adult anthropometric and strength measurements. Nottingham, U.K.: University of Nottingham, Product Safety and Testing Group, 2011.

53. Komar D, Grivas C. Manufactured populations: what do contemporary reference skeletal collections represent? A comparative study using the Maxwell museum documented collection Am J Phys Anthrop 2008;137:224-33.

Additional information and reprint requests:

Carme Rissech, Ph.D

Unitat d'Antropologia Física

Departament de Biologia Animal

Facultat de Biologia

Universitat de Barcelona

08028 Barcelona

Spain

E-mail: carme.rissech@ub.edu 


\section{Author Query Form}

\section{Journal: $\quad$ JFO}

Article: $\quad 12011$

Dear Author,

During the copy-editing of your paper, the following queries arose. Please respond to these by marking up your proofs with the necessary changes/additions. Please write your answers on the query sheet if there is insufficient space on the page proofs. Please write clearly and follow the conventions shown on the attached corrections sheet. If returning the proof by fax do not write too close to the paper's edge. Please remember that illegible mark-ups may delay publication.

Many thanks for your assistance.

\begin{tabular}{|l|l|l|}
\hline Query reference & Query & Remarks \\
\hline 1 & AUTHOR: Please check that authors and their affiliations are correct. \\
\hline 3 & AUTHOR: Please provide the volume number for reference [36]. \\
\hline 4 & AUTHOR: Please provide the volume number for reference [50]. \\
\hline
\end{tabular}




\section{Proof Correction Marks}

Please correct and return your proofs using the proof correction marks below. For a more detailed look at using these marks please reference the most recent edition of The Chicago Manual of Style and visit them on the Web at: http://www.chicagomanualofstyle.org/home. html

\begin{tabular}{|c|c|c|}
\hline Instruction to typesetter & Textual mark & Marginal mark \\
\hline Leave unchanged & $\cdots$ under matter to remain & (stet) \\
\hline $\begin{array}{l}\text { Insert in text the matter } \\
\text { indicated in the margin }\end{array}$ & $\wedge$ & $\begin{array}{l}\wedge \text { followed by new } \\
\text { matter }\end{array}$ \\
\hline Delete & $\sigma_{\text {through single character, rule or underline }}$ & matter \\
\hline $\begin{array}{l}\text { Substitute character or } \\
\text { substitute part of one or } \\
\text { more word(s) }\end{array}$ & $\begin{array}{l}\mathcal{I} \text { through all characters to be deleted } \\
K \text { through letter or } \\
\end{array}$ & $\begin{array}{l}\text { new character } \lambda \text { or } \\
\text { new characters } \lambda\end{array}$ \\
\hline Change to italics & — under matter to be changed & ital \\
\hline Change to capitals & $\equiv$ under matter to be changed & caps \\
\hline Change to small capitals & $=$ under matter to be changed & (5e) \\
\hline Change to bold type & $\approx$ under matter to be changed & (4f) \\
\hline Change to bold italic & $\bar{\sim}$ under matter to be changed & offital \\
\hline Change to lower case & B & (b) \\
\hline Insert superscript & $\checkmark$ & $\begin{array}{l}\vee \text { under character } \\
\text { e.g. } \vee\end{array}$ \\
\hline Insert subscript & $\wedge$ & $\begin{array}{l}\wedge \text { over character } \\
\text { e.g. } 1\end{array}$ \\
\hline Insert full stop & $\odot$ & $\odot$ \\
\hline Insert comma & $\hat{\jmath}$ & $\hat{\jmath}$ \\
\hline Insert single quotation marks & $\sqrt{2}$ & 22 \\
\hline Insert double quotation marks & $\ddot{v}$ & 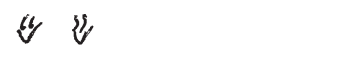 \\
\hline Insert hyphen & $=$ & $=$ \\
\hline Start new paragraph & 4 & 4 \\
\hline Transpose & $\sqcup$ & $\sqcup$ \\
\hline Close up & linking 2 characters & 2 \\
\hline $\begin{array}{l}\text { Insert or substitute space } \\
\text { between characters or words }\end{array}$ & \# & \# \\
\hline $\begin{array}{l}\text { Reduce space between } \\
\text { characters or words }\end{array}$ & J & J \\
\hline
\end{tabular}

